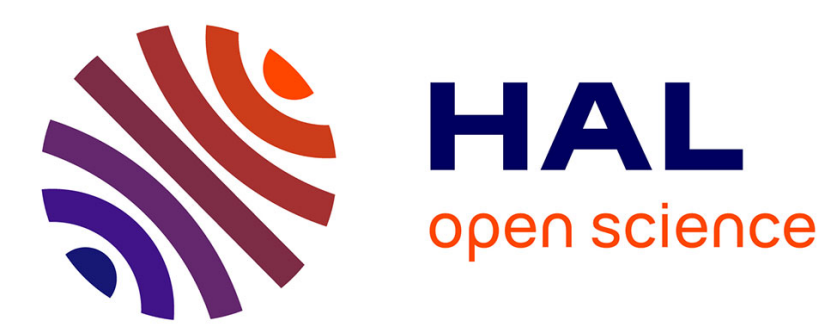

\title{
Trust and the Welfare State: The Twin Peaks Curve
} Yann Algan, Pierre Cahuc, Marc Sangnier

\section{- To cite this version:}

Yann Algan, Pierre Cahuc, Marc Sangnier. Trust and the Welfare State: The Twin Peaks Curve. 2014. halshs-01000117

\section{HAL Id: halshs-01000117 https://shs.hal.science/halshs-01000117}

Preprint submitted on 4 Jun 2014

HAL is a multi-disciplinary open access archive for the deposit and dissemination of scientific research documents, whether they are published or not. The documents may come from teaching and research institutions in France or abroad, or from public or private research centers.
L'archive ouverte pluridisciplinaire HAL, est destinée au dépôt et à la diffusion de documents scientifiques de niveau recherche, publiés ou non, émanant des établissements d'enseignement et de recherche français ou étrangers, des laboratoires publics ou privés. 


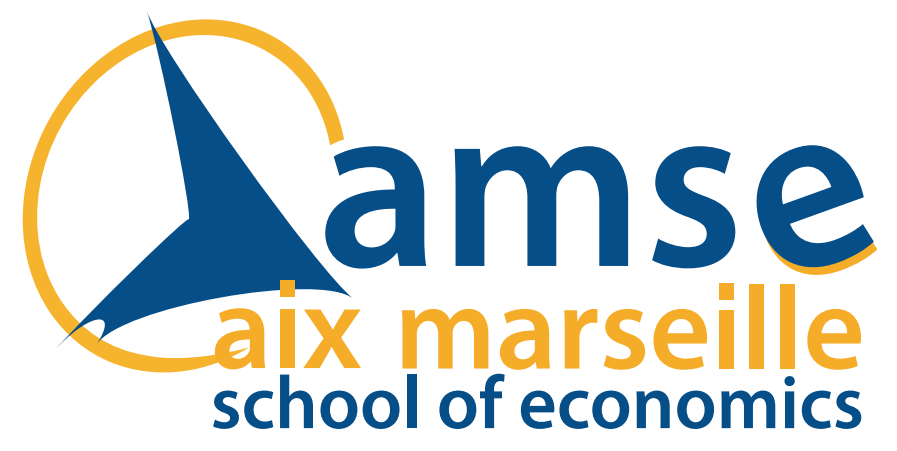

\section{Working Papers / Documents de travail}

Trust and the Welfare State: The Twin Peaks Curve

Yann Algan

Pierre Cahuc

Marc Sangnier 


\title{
Trust and the Welfare State: the Twin Peaks Curve*
}

\author{
Yann Algan** $\quad$ Pierre Cahuc*** Marc Sangnier $^{\S}$
}

June 2014

\begin{abstract}
We show the existence of a twin peaks relation between trust and the size of the welfare state that stems from two opposing forces. Uncivic people support large welfare states because they expect to benefit from them without bearing their costs. But civic individuals support generous benefits and high taxes only when they are surrounded by trustworthy individuals. We provide empirical evidence for these behaviors and this twin peaks relation in the OECD countries.
\end{abstract}

KEYWORDS: Welfare state, trust, civism, corruption, redistribution.

JEL CODES: H1, Z1.

*This paper was previously circulated under the title "Efficient and Inefficient Welfare States".

**Sciences Po. Email address: yann.algan@sciences-po.fr. The research leading to these results has received funding from the European Research Council for Yann Algan under the European Community Seventh Framework Programme (FP7/2007-2013) / ERC grant agreement no 240923.

*** CREST-ENSAE, École Polytechnique, IZA, CEPR. Email address: cahuc@ensae.fr.

$\S$ Aix-Marseille Univ. (Aix-Marseille School of Economics), CNRS \& EHESS. Email address: marc.sangnier@univ-amu.fr. 


\section{Introduction}

Why does the welfare state take such a variety of different forms across countries? To this long-established question a recent literature responds with the hypothesis that the size of the welfare state depends positively on the country level of trust. In particular, Rothstein and Uslaner (2005) and Rothstein et al. (2010) argue that the persistence of large welfare states in Scandinavian countries is explained by the trustworthiness of their citizens. Those large welfare states, it is argued, rely on conditional cooperation. Trustworthy, or "civic" individuals consent to pay high rates of tax only because they are convinced that their compatriots are paying their taxes too, and not misusing social benefits.

We will show that this explanation is only one part of a much broader story. Figure 1 (a) shows that the observed cross-country relationship between trust and the size of welfare states is not monotonic, contrary to the traditional claim, but can be visualized as twin peaks. Although Austria, Belgium, France, Germany and Italy display limited trust, their welfare states are as large as those of Scandinavian countries. Similarly, Figure 1[(b) shows a twin peaks relation between the transparency and the size of the different OECD welfare states. Our paper provides a rational and testable prediction for this puzzle. We argue that this twin peaks curve arises from a conflict inherent in the attitudes of civic and uncivic individuals towards the welfare state. Uncivic citizens, the sort who evade their tax obligations while seeking to extract all they can from social benefits, will support the expansion of the welfare state more strongly than civic citizens will, since they expect to benefit the most from it while shirking the costs. A rise in the share of uncivic citizens could thus increase the demand for a generous welfare state. However, an opposing force is also at play. Civic citizens will be less inclined to support high taxes if they expect to be surrounded by uncivic individuals who do not pay taxes and abuse social benefits.

The first part of the paper develops a political economy model where these two opposing forces can lead to a twin peaks relation between trust and the size of the welfare state. The model comprises trustworthy and untrustworthy individuals. Civic individuals cheat neither on taxes nor on social benefits. Uncivic individuals cheat on both taxes and social benefits if this is in their own interest. The model predicts that the first peak of the twin peaks relation appears at the point where political power shifts from untrustworthy to trustworthy citizens. This shift is associated with an immediate drop in support for the welfare state, since trustworthy citizens are less favorable to redistribution than untrustworthy citizens. The second peak appears when everyone is civic. In this situation, all individuals strongly support the welfare state because nobody cheats on taxes and social benefits.

Next, we extend the model to take into consideration the behavior of the civil servants who administer the welfare state. We make the plausible assumption that the civic spirit obtaining among public officials will mirror that of the population. The model can then generate the observed twin peaks relation between the transparency and the size of the welfare state 
documented in Figure 11(b). Overall, the model lays down the theoretical foundations for the existence of a large and corrupt welfare state in a society populated by numerous untrustworthy individuals who cheat on social benefits and dodge their taxes. Conversely, the welfare state can be both large and transparent - but only if the share of trustworthy individuals is sufficiently large. The model can thus explain the existence of support for large welfare states in both low-trust and high-trust countries, but with very contrasting degrees of transparency.

We then test the predictions and mechanisms of the model with both macro and micro evidence. We start by providing macro evidence for the twin peaks curve across OECD countries. We perform piecewise linear regressions - letting the data endogenously determine the breakpoint - between various measures of the generosity of the welfare state and a handful of measures of trust and trustworthiness. We check the robustness of the results by controlling for alternative variables - ethnic segmentation, democracy score, and real GDP per capita - that have been found to influence the size of the welfare state. We then test the main individual mechanisms of the model by using international social surveys. From the World Values Survey, we find that uncivic individuals support the welfare state more strongly than civic ones. In particular, individuals who declare that it may be excusable to claim government benefits to which they are not entitled or to avoid a fare on public transport, are found to support more generous social programs than trustworthy individuals who declare that there is never an excuse for cheating. From the European Social Survey, we also find that individuals who think that they are surrounded by people of a more trustworthy kind exhibit a stronger degree of support for the welfare state.

Our paper follows two strands of related research. The first strand deals with the existence of a positive and monotonic relationship between trust and the welfare state. In particular in political science, Hetherington (1998, 2004) argues that the decline in political trust has played a central role in the demise of progressive policy in the United States over the last several decades. Rothstein and Uslaner (2005), Rothstein et al. (2010), Bergh and Bjørnskov (2011), and Bjørnskov and Svendsen (2013) claim that the scope of the welfare state in OECD countries is limited by distrust towards others and towards governmental institutions. The lineage of the notion can be traced to Adam Smith, who stressed in The Wealth of Nations that "where the people have entire confidence in their magistrates, are convinced of the necessity of the tax for the support of the state, and believe that it will be faithfully applied to that purpose, such conscientious and voluntary payment may sometimes be expected." 11 This explanation fits well with the specific group of very high-trusting countries. But it cannot account for the existence of large and non-transparent welfare states in very low-trusting countries. Our paper stands out from this strand of research in at least two ways. First, we provide a rationale for the existence of a twin peaks curve. We also explain why large welfare states might be supported in both high-trusting and low-trusting countries, but are transparent in the former group of

\footnotetext{
${ }^{1}$ Smith $(1904)$, book V, chapter II. See Evensky $(2005)$ for a thorough discussion.
} 
countries only. Second, we provide macro and micro evidence on the twin peaks relationship between trust and support for the welfare state.

A second research theme emerges out of the economics of redistribution. The seminal explanations of the support for redistribution looked at the distribution of incomes before taxes and transfers (see Alesina and Glaeser 2004) and at prevailing beliefs about income mobility (Piketty 1995, Bénabou and Ok 2001, Alesina and La Ferrara 2005). Alternative explanations of the demand for redistribution have stressed the role of fairness (Corneo and Gruner 2002, \begin{tabular}{|l|l|l|l|l|}
\hline Alesina and Angeletos 2005, Luttens and Valfort 2008), reciprocal altruism (Fong 2001, Fong \\
\hline
\end{tabular} et al. 2006), inherited preference ingrained in past historical experience (Corneo and Gruner 2002, Alesina and Fuchs-Schündeln 2007, Luttmer and Singhal 2011, Alesina and Giuliano 2011), ethnic segmentation and group loyalty (Luttmer 2001 and Alesina and Glaeser 2004), the desire to act in accordance with public values (Corneo and Gruner 2002), and the role of the electoral system (Alesina et al. 2001 and Persson and Tabellini 2002). The originality of our contribution is to stress the central role of what might be called "civicness" and beliefs in the trustworthiness of others. In particular, we exploit specific questions about the perceived behavior of compatriots with respect to various social benefits and we show that these perceived behaviors are significantly associated with support for the welfare state.

The paper is organized as follows. Section 2 presents a model that rationalizes the twin peaks relation between trust and the size of the welfare state. Section 3 provides evidence for the twin peaks curve for OECD countries. Section 4 tests the main predictions of the model at the individual level. Section 5 concludes.

\section{The model}

This section analyzes the theoretical foundations of the relationship between trust, trustworthiness and the scope of the welfare state.

\subsection{The setup}

There is a continuum of individuals of measure one and a government which levies taxes and provides social benefits. Every individual is either trustworthy or untrustworthy. The share of trustworthy (or "civic") individuals is denoted by $\alpha \in[0,1]$. Civic individuals pay taxes and only claim benefits to which they are entitled. Untrustworthy (or "uncivic") individuals are purely opportunistic: they cheat on taxes and social benefits whenever this can raise their income. All individuals have the same preferences over consumption. For the sake of simplicity, we use a logarithmic utility function $\ln (c)$, where $c$ stands for consumption.

Every individual produces $y>0$ units of the consumption good with probability $\pi \in(0,1)$ and a lower level, denoted by $y_{0} \in(0, y)$, with probability $1-\pi$. Productive individuals, who produce $y$, must pay a tax, denoted by $t$, to finance benefits, denoted by $b$, provided to those 
who produce $y_{0}$. Productive individuals can hide their production with probability $1-p$. For instance, if it is possible for them to work in the informal sector, their production cannot be observed by the government. Civic individuals always declare their true level of production. Thus, they pay the required tax if they are productive and they claim benefits only if they produce the low level $y_{0}$. Uncivic individuals able to hide their production never pay taxes and always claim benefits whatever their level of production.

The timing of events is as follows. First, individuals are born either civic or uncivic. Second, individuals vote on benefits and taxes. Third, a share $\pi$ of individuals produce $y$ and a share $1-\pi$ produce $y_{0}$. Then, taxes are paid and benefits are distributed.

\subsection{Support for the welfare state}

We first analyze the degree of support for the welfare state from civic and uncivic individuals. Every individual prefers the settings of tax and benefits that maximize her expected utility subject to the budget constraint of the government. The tax receipt of the government comes from the tax paid by the $\pi \alpha$ productive civic individuals and from the $p \pi(1-\alpha)$ productive uncivic individuals whose production cannot be hidden. The benefits are provided to the $(1-\pi)$ unproductive individuals and to the $\pi(1-p)(1-\alpha)$ productive uncivic individuals who can claim benefits because their production can be hidden. Accordingly, the budget constraint of the government is

$$
\pi t[\alpha+p(1-\alpha)]=[(1-\pi)+\pi(1-p)(1-\alpha)] b .
$$

- Civic individuals expect to pay the tax $t$ if they are productive and to get benefits $b$ otherwise. Their preferred taxes and benefits maximize

$$
\pi \ln (y-t)+(1-\pi) \ln \left(y_{0}+b\right)
$$

subject to the budget constraint (1). ${ }^{2}$ The optimal tax is

$$
t_{\text {civic }}=(1-\pi) y-\frac{(1-\pi)+\pi(1-p)(1-\alpha)}{\alpha+p(1-\alpha)} y_{0} \geq 0
$$

This equation shows that the preferred tax of civic individuals increases with the share of civic individuals. The reason is that the proportion of people abusing social benefits is smaller when the share of civic individuals is greater. Accordingly, the welfare state provides social insurance more effectively, the more civic individuals there are. This fosters support for the welfare state. In the limit case where all individuals are civic $(\alpha=1)$, the tax, equal to $(1-\pi)\left(y-y_{0}\right)$, is necessarily positive. However, as the share of civic individuals becomes smaller, the preferred tax of civic individuals will drop. It

\footnotetext{
${ }^{2}$ The logarithmic utility function implies that the optimal tax always satisfies $t<y$. This condition holds true for civic and uncivic individuals.
} 
can even drop to zero if the probability $p$ of tax evasion being detected is small enough: below the threshold $\bar{p}=y_{0} /\left[y+\pi\left(y_{0}-y\right)\right]$. In this case, the share of people who pay tax is so small with respect to the share of people who get benefits that civic individuals become unwilling to pay taxes, because the return to taxes has become too small. In what follows, we shall assume, for the sake of simplicity, that the probability of tax evasion being detected is above the threshold $\bar{p}$ so that the optimal tax chosen by civic individuals is always positive. Once the tax $t_{\text {civic }}$ is known, it is possible, using the budget constraint (1), to compute the preferred benefits $b_{\text {civic }}$ of civic individuals. From this, we can compute the ratio of consumption of unproductive individuals, $y_{0}+b$, over consumption of productive individuals, $y-t$, chosen by civic individuals, which takes the value:

$$
\rho_{\text {civic }} \equiv \frac{y_{0}+b_{\text {civic }}}{y-t_{\text {civic }}}=\frac{\alpha+p(1-\alpha)}{1+\frac{\pi}{(1-\pi)}(1-p)(1-\alpha)} .
$$

This equation shows that there is full insurance, i.e. $y_{0}+b_{\text {civic }}=y-t_{\text {civic }}$, when everyone is civic, i.e. when $\alpha=1$. When there are uncivic individuals in the population, there is partial insurance.

- The preferred taxes and benefits of uncivic individuals maximize

$$
\pi[p \ln (y-t)+(1-p) \ln (y+b)]+(1-\pi) \ln \left(y_{0}+b\right)
$$

subject to the budget constraint (1). This entails that the ratio of the consumption of unproductive individuals, $y_{0}+b$, over the consumption of productive individuals, $y-t$, chosen by uncivic individuals can be written.

$$
\rho_{\text {uncivic }} \equiv \frac{y_{0}+b_{\text {uncivic }}}{y-t_{\text {uncivic }}}=\frac{\rho_{\text {civic }}}{p}\left(1+\frac{1}{1-\pi} \frac{y_{0}+b}{y+b}\right)
$$

Support for the welfare state on the part of uncivic individuals increases with the share of civic individuals ( part of civic individuals does. The model also predicts that uncivic individuals desire more redistribution than civic individuals (since the ratio $\left(y_{0}+b\right) /(y-t)$ defined by equation (6) is larger than that defined by equation (4) ). Uncivic individuals desire more redistribution for two reasons. First, they benefit from public transfers more frequently than civic individuals since they claim benefits when their production can be hidden. Second, they do not bear the full burden of taxation since they dodge taxes when this is possible.

At this stage, the predictions of the model are that uncivic individuals want more redistribution than civic individuals and that all individuals want more redistribution when they expect to be surrounded by more civic individuals. 


\subsection{The outcome of the vote}

Individuals vote on the levels of taxes and benefits that are compatible with the budget constraint. Since preferences are single-peaked, we can assume that the outcome of the vote is defined by the median voter. Taxes are determined by uncivic individuals if the share of civic individuals is smaller than $\frac{1}{2}$ and by civic individuals otherwise. The outcome is represented in figure 2. The relation between the share of civic individuals and the level of social insurance displays twin peaks because the support for the welfare state from uncivic individuals is greater than that of civic individuals. Large welfare states can be supported by a majority of uncivic individuals who cheat on taxes and benefits. This can explain why countries with a large share of uncivic individuals like Italy, France and Belgium, can have welfare states as large as civic countries like the Scandinavian nations.

Moreover, when the median voter is uncivic, the size of the welfare state is inefficiently high. The maximization of any convex combination of the utilities of civic and uncivic individuals would yield a lower tax level than the one picked by the median voter.

\subsection{Accounting for the transparency of the welfare state}

So far, we have assumed that the effectiveness of the welfare state, defined by its ability to collect taxes and to provide transfers, was given. However, the effectiveness of the state might also depend on the behavior of officials. It is likely that the civic spirit of officials reflects the civic spirit of citizens at large. Governments are expected to be more corrupt and less effective in societies where individuals are less civic.

To take this relation into account, we consider an extension of the model (presented in the Online Appendix) that incorporates the behavior of officials who levy taxes. Every individual is working during the day and is an official at night. Civic officials do their duty: they levy taxes which are used to distribute benefits. Uncivic officials are corrupt: they capture the tax they collect. This framework allows us to account in a simple way for the fact that the share of uncivic officials is more likely to be higher when there are more uncivic individuals in the society.

The extended model displays the same twin peaks relationship between the share of civic individuals and the size of the welfare state. But it yields additional predictions. This theoretical extension allows us to predict a non-monotonic relation between the transparency (or the effectiveness) of welfare states and their size. Societies populated by a majority of uncivic individuals can support corrupt and ineffective welfare states that can be larger than the more effective welfare states of societies populated by a majority of civic individuals. This prediction is consistent with Esping-Andersen s characterization of welfare states. The corporatist welfare states characteristic of societies with an intermediate level of civicness, such as Belgium, Germany, Italy, and Austria (see figure 1](a)], do not redistribute very much from the rich to 
the poor, although they are as large as the Nordic welfare states. Our extended model echoes Milanovic's idea that the motives behind the redistributive activity of the state differ across countries (see Milanovic 2000 among others).

\subsection{Trustworthiness as a continuous variable}

The results presented to this point flowed from a model where trustworthiness is a binary variable. But these results retain validity if trustworthiness is a continuous variable. Assume that there is a utility cost $T$ to being uncivic $(T \geq 0)$. $T$ can be interpreted as a measure of trustworthiness. It is distributed in the population with the cumulative distribution function denoted by $F$, which is assumed to be continuous. Let $V_{\text {uncivic }}$ denote the expected utility of individuals who behave in an uncivic way (defined by equation (5)) and let $V_{\text {civic }}$ denote the expected utility of individuals who behave in a civic way (defined by equation (2)). Individuals decide to be civic if $V_{\text {civic }}>V_{\text {uncivic }}-T$. Therefore, the proportion of civic individuals in the population is $\alpha=1-F\left(V_{\text {civic }}-V_{\text {uncivic }}\right)$. In this setup, the share of civic individuals becomes endogenous. Since individuals solve the same type of problem as in the benchmark model where trustworthiness is a binary variable, it can be verified (see the Online Appendix) that every individual wants more welfare state when the share of civic individuals in the population bulks larger. For the same reason, uncivic individuals desire more taxes and benefits than civic individuals.

Assume now that the distribution of $T$ changes according to the mapping $M: F(T) \rightarrow$ $\tilde{F}(T)=F(T)-\Delta(T)$, with $\Delta(T) \geq 0$. We thus associate with the distribution $F$ a new distribution $\tilde{F}$ with a larger share of trustworthy individuals (i.e. individuals with high values of $T$ ). If the change in the distribution is such that the majority of individuals remains either civic or uncivic, the increase in the share of trustworthy individuals induces an increase in the size of the welfare state since every individual wants more welfare state when the share of civic individuals in the population grows larger. If there is a small change in the distribution which implies that the majority of individuals switches from uncivic to civic behavior, there is a drop in support for the welfare state because civic individuals want less taxes and benefits than uncivic individuals.

In conclusion, the twin peaks relation between the share of civic individuals and the size of the welfare state can be derived in a context where trustworthiness is a continuous variable rather than a binary one.

\section{Macro-level evidence}

In this section, we test the prediction of the model at the aggregate level. Our model predicts that the relationship between the share of trustworthy individuals and the scope of redistribution is discontinuous. It displays twin peaks with two increasing relations. To test this 
prediction, we implement piecewise regressions with an endogenous breakpoint, where the dependent variable is a measure of the generosity of the welfare state and the right-hand variable of interest captures the share of trustworthy individuals.

\subsection{Data and methodology}

We use four different measures of the size of the welfare state at the country level. The first two measures are from the OECD Social Expenditure Database: the share of total public social expenditure in percentage of GDP, and per capita public social expenditure. The third measure is the overall generosity score of the welfare state, computed by Scruggs (2004). . $^{3}$ The last measure is the share gain of the bottom two deciles computed by Milanovic (2000).4

Parameter $\alpha$ of the model represents the share of trustworthy individuals. It is measured with the country's share of respondents who answer "never justifiable" to the following question from the World Values Survey: "Please tell me for each of the following statements whether you think it can always be justified, never be justified, or something in between [...]: Claiming government benefits to which you are not entitled." This variable is labeled civism in the analysis. According to the model, the parameter $\alpha$ can also be interpreted as the perceived share of trustworthy individuals. We thus use an alternative measure based on the share of respondents who answer "most people can be trusted" to the following question from the World Values Survey: "Generally speaking, would you say that most people can be trusted or that you need to be very careful in dealing with people?" This variable is referred to as trust in the empirical analysis. Finally, the model also predicts that parameter $\alpha$ is positively related to the perceived corruption of the welfare state. We test this relation by using the corruption perception index from Transparency International and label it corruption perception. 5

In order to uncover the twin peaks relationship between the generosity of the welfare state and the share $\alpha$ of trustworthy individuals, we estimate the following model:

$$
\begin{cases}z_{i}=a_{1}+b_{1} x_{i}+\varepsilon_{i}, & \text { if } x_{i}<\gamma \\ z_{i}=a_{2}+b_{2} x_{i}+\varepsilon_{i}, & \text { if } x_{i} \geq \gamma\end{cases}
$$

where $z_{i}$ is welfare state generosity, $x_{i}$ is the measure of the model's parameter $\alpha$ in country $i$, and $\gamma$ is the breakpoint to be determined by the data. We estimate these equations using ordi-

\footnotetext{
$3^{3}$ Scruggs (2004)'s generosity score summarizes the generosity of three social insurance programs: sickness, unemployment and pension. Calculations are based on an average productive worker. For each program and each country, a score is assigned following the program's characteristics (replacement rate, qualification conditions, duration, etc.) and coverage. The final index is computed as the sum of the three scores and reflects increasing generosity of the system.

${ }^{4}$ The share gain of a given decile is defined by Milanovic (2000) as "the difference between the share of [this] decile in factor and [the share of this decile in] disposable income".

${ }^{5}$ The number of countries is unbalanced across the different waves of the World Values Survey. We thus use the questionnaires from 1995, 2000, and 2005, and compute averages of civism and trust across waves for which the welfare states generosity data are available. The same remarks apply for corruption perception.
} 
nary least squares regressions and bootstrapped standard errors to account for the small sample size. The optimal breakpoint is chosen as the value of $\gamma$ that minimizes the overall residual sum of squares across both groups of observations. To determine the breakpoint endogenously, we use the method developed by Andrews (1993, 2003) building on Quandt (1960). This method is grounded in the observation that the correct test statistic is the maximum $\mathbb{F}$-statistic over the whole procedure - i.e. over all candidates' breakpoints - and does not follow a standard distribution (see Hansen 2001 for a clear presentation). To the best of our knowledge, the distribution of this statistic is unknown for finite samples. Hence, we construct p-values of this distribution using a bootstrap procedure as described by Diebold and Chen (1996) ${ }^{6}$

\subsection{Results}

Table 1 displays the estimated coefficients from the model above. The right-hand variable is civism. In the first column, the dependent variable is the share of total public social expenditure in GDP. This column shows that the standard test by Chow (1960) strongly rejects the null hypothesis of a single regime. When we apply the method developed by Andrews 1993 , 2003) to let the breakpoint be determined by the data, we get a p-value of 0.01 that rejects the hypothesis that only one regime exists. We also use the bootstrap procedure to test for differences in intercepts and slopes on both sides of the breakpoint, and to test for the existence of a discontinuity at break, such that p-values of these tests also take into account that the breakpoint has been endogenously determined. The test for the discontinuity at the breakpoint yields a p-value of 0.02 that confirms that countries just below the threshold exhibit substantially higher generosity of their welfare state than countries just above it. Moreover, we uncover an increasing relationship between civism and the size of the welfare state on each side of the breakpoint, in line with the prediction of the theoretical model. The relation is positive and strongly significant above the breakpoint. Below the breakpoint, the relationship is positive, although not statistically significant.

We check the robustness of the results by controlling for the alternative determinants of the demand for redistribution proposed by the literature so far, such as ethnic segmentation (Luttmer 2001 and Alesina and Glaeser 2004), and the electoral system (Alesina et al. 2001 and Persson and Tabellini 2002). We include in the regressions ethnic segmentation- from Alesina et al. (2003) - , the level of democracy - using the imputed polity score from Freedom House -, and the (log of) real GDP per capita in piecewise regressions for OECD countries. To achieve this, we first regress the country level of redistribution on these determinants. Then, we regress the residuals from this estimation on civism. This two-step procedure tests whether the relation between welfare state generosity and civism has two regimes, conditional on the other potential determinants of the welfare state. The estimated coefficients are presented in the second column of Table 1. The formal statistical tests reject the hypothesis that data come

\footnotetext{
${ }^{6}$ See the Online Appendix for the detailed presentation of the procedure.
} 
from one regime and support the alternative that data are generated by two regimes. Also, the hypothesis of no discontinuity in the relationship between civism and the conditional share of total public social expenditure is rejected. We still find a positive relation between the scope of the welfare state and civism on each side of the breakpoint.

We replicate the same analysis with alternative measures of the size of the welfare state in columns 3 to 8 of Table 1. With those alternative measures we do find a statistically significant twin peaks relation, despite the fact that Scruggs (2004)'s generosity score and Milanovic (2000)'s share gain are available for a smaller sample of countries. We find only a mixed result for the share gain of the bottom two deciles. The Chow-p value rejects the null hypothesis of a single regime but the Quandt-Andrews p-value does not. Another interesting result is the stability of the estimated coefficient for the endogenous breakpoint. We observe only slight variation in its value despite changes in dependent variables and samples.

Tables 2 and 3 replicate the estimations discussed above with trust and corruption perception as the right-hand variable instead of civism. Table 2 shows the results for trust. We find strong evidence of a twin peaks relationship with the various measures of the welfare state's generosity. As with civism, the only inconclusive result comes from the measurement of the conditional generosity score: the Chow-p value rejects the null hypothesis of a single regime but the Quandt-Andrews p-value does not. Table 3 shows the result with the corruption perception index as the right-hand variable. The evidence of the existence of two regimes is weaker. But overall results confirm the existence of a discontinuity in the relationship.

In conclusion, Tables 13 reject the hypothesis of a monotonous and continuous relation between trust, civism, and perceived corruption on one hand, and the size of welfare state on the other hand. In line with the prediction of our theoretical model, the evidence supports the existence of a twin peaks relation, as illustrated by figures 1 (a) and 1 (b).

\section{Individual-level evidence}

The model shows that the twin peaks relation between trust and the size of the welfare state arises from the two types of individual behavior predicted by the model. First, untrustworthy individuals want more redistribution than trustworthy individuals. Second, individuals provide more support for the welfare state when they think that they are surrounded by more trustworthy individuals. We test those individual-level predictions on micro-data from the World Values Survey (WVS) and the European Social Survey (ESS).

The empirical evidence presented below is based on regressions of individuals' opinions on other subjective variables. This setting calls for prudent interpretation in terms of causality. Both variables may be correlated because of omitted factors, and the right-hand variable may also be a rationalization for the left-hand one 7 Although we do not claim causality, we show

\footnotetext{
${ }^{7}$ See Hamermesh (2004) among others for a thoughtful discussion of related issues.
} 
that the empirical individual behavior predicted by the model is consistent with micro evidence.

\subsection{Civic spirit}

Our model predicts that uncivic individuals want more redistribution than civic individuals because they are the ones eluding taxation and abusing social benefits. We use the WVS to test this prediction. We measure civicness by using the following questions: "Please tell me for each of the following statements whether you think it can always be justified, never be justified, or something in between, using this card." We use answers to the following statements: "Claiming government benefits to which you are not entitled"; "Avoiding a fare on public transport"; "Cheating on taxes when you have a chance"; "Someone accepting a bribe in the course of their duties"; "Throwing away litter in a public place"; "Buying stolen goods". The answers range from 1 for "never justifiable" to 10 for "always justifiable." Depending on the question, around 60 to 70 percent of respondents answer "never justifiable" to these questions. The other answers are chosen by small and equally distributed shares of respondents. We thus distinguish two main types of individuals: those who claim that the behaviors described in the questions are "never justifiable" and those who say that they can be justifiable in some cases. For each question, we create a variable measuring civic spirit which is equal to 1 if the answer is "never justifiable" and 0 for all other answers.

From the WVS, we measure support for the welfare state with the question: "I'd like you to tell me your views on various issues. How would you place your views on this scale? 1 means you agree completely with the statement on the left; 10 means you agree completely with the statement on the right; and if your views fall somewhere in between, you can choose any number in between. Incomes should be made more equal versus We need larger income differences as incentives." We reverse the scale of the answers such that a higher score indicates greater support for the welfare state.

The relation between civic spirit and support for the welfare state is displayed in columns 1 to 6 of table 4. The explanatory variable of interest is civicness. In all specifications, we include controls for age, gender, education, income of the household, family status, employment status, political orientation and religiosity - as defined in table A1 presented in the Online Appendix -, country fixed effects and time fixed effects for the year of interview. Although we are using qualitative variables as dependent variables, all coefficients presented in this paper are obtained using ordinary least squares to ease the interpretation of coefficients. The results are qualitatively and quantitatively not sensitive to the use of ordered probit or ordered logit estimation techniques.

Whatever the measure of civicness, the estimated coefficient of civic spirit is negative and statistically significant. This means that civic individuals want less redistribution than uncivic individuals, as predicted by the model. The estimated effect of being civic on support for the

welfare state is as large as the effect of gender (or even larger in some cases); and it is as large 
as the effect of being unemployed instead of employed 8

\subsection{Generalized trust and perceived behavior of compatriots}

Another important prediction of the model is the existence of a positive relation between generalized trust, in particular the perceived trustworthiness of others, and support for the welfare state. From the WVS, we use the same question on generalized trust as in the macroevidence section. Column 7 of Table 4 shows a positive and statistically significant relationship between generalized trust and support for the welfare state by using the WVS.

We also exploit the fourth round of the ESS - conducted in 2008 and 2009 - that provides a specific module on attitudes towards the welfare state. This survey contains a well-designed measure of support for redistribution by formulating the following question: "Many social benefits and services are paid for by taxes. If the government had to choose between increasing taxes and spending more on social benefits and services, or decreasing taxes and spending less on social benefits and services, which should they do?" Answers range from 0, "Government should decrease taxes a lot and spend much less on social benefits and services," to 10, "Government should increase taxes a lot and spend much more on social benefits and services." This scale clearly reflects a graduation in support for the welfare state. Its wording has the advantage of stressing both the costs and the benefits of the welfare state. This question is also much more explicit regarding the demand for the welfare state than the ones related to the role of government in reducing inequalities, traditionally used in the literature (see Alesina and Giuliano 2011). Besides, the question makes explicit reference to the government of the country of interview. It is preceded by a series of questions about social benefits and the tax authorities which make reference to the country where people are being interviewed. We use all countries for which the variables in which we are interested are available.9

Table 5, illustrates the relationship between trust and support for the welfare state. The dependent variable is the ESS question on support for the welfare state. All regressions include controls for age, gender, education, income of the household, family status, employment status, political orientation and religiosity - as defined in table A2 presented in the Online Appendix - , and country fixed effects.

In column 1 of table 5, the explanatory variable is generalized trust. It is measured by the question: "Generally speaking, would you say that most people can be trusted or that you need to be very careful in dealing with people?" The variable ranges from 0 for "You can't be

\footnotetext{
${ }^{8}$ It might be argued that the civicness-related questions we use reflect certain opinions regarding the poor rather than actual individual civicness. Yet, two remarks may help to alleviate this concern. First, we control for political orientation and income, two variables that are likely to capture part of individuals' attitudes toward the poor. Second, the civicness question about littering provides an estimate that is in line with our predictions and does not seem to suffer from such an alternative interpretation.

${ }^{9}$ Belgium, Croatia, Czech Republic, Denmark, Finland, France, Germany, Greece, Hungary, Israel, Latvia, Netherlands, Norway, Poland, Portugal, Romania, Russia, Slovenia, Spain, Sweden, Switzerland, Turkey, Ukraine, United Kingdom.
} 
too careful" to 10 for "Most people can be trusted." The coefficient associated with trust is positive and significant at the $1 \%$ level. The magnitude of the coefficient is significant. The fact of claiming that "Most people can be trusted" rather than "You can't be too careful" is associated with an increase in support for the welfare state which is four times larger than the difference between the demand for redistribution from the unemployed relative to the demand for redistribution from those in employment. The coefficient associated with political orientation shows that right-wing individuals express less support for the welfare state. A rise of one point in the 0-10 distrust-trust scale is associated with about half the effect on the demand for redistribution of a one point rise in the 0-10 left-right scale. The coefficient associated with income is not significantly different from zero, suggesting that support for the welfare state is not significantly influenced by income. Education is positively correlated with support for the welfare state, but its coefficient is five times smaller than the coefficient associated with trust.

The ESS also provides detailed questions about the perceived trustworthiness of compatriots. Column 2 of table 5 uses the following question: "Do you think that most people would try to take advantage of you if they got the chance, or would they try to be fair?" The variable is equal to 0 if the respondent answered "Most people would try to take advantage of me" and 10 if the answer is "Most people would try to be fair." Column 3 shows the results obtained when the question is: "Would you say that most of the time people try to be helpful or that they are mostly looking out for themselves?" The variable is equal to 0 if the respondent answered "People mostly look out for themselves" and 10 if the answer is "People mostly try to be helpful." In both cases, these measures of the perceived trustworthiness of others are positively associated with support for redistribution. The coefficients are statistically significant at the $1 \%$ level.

We then turn to three more specific questions on the behavior of compatriots with respect to social benefits. The questions read: "Many people manage to obtain benefits and services to which they are not entitled"; "Most unemployed people do not really try to find a job"; and "Employees often pretend they are sick in order to stay at home." For each question, the answers range from 1 for "strongly agree" to 5 for "strongly disagree."

Column 4 of table 5 shows that beliefs about the way compatriots are (mis)using social benefits is strongly associated with individual support for the welfare state. The fact of agreeing strongly rather that disagreeing strongly with the claim "Many people manage to obtain benefits and services to which they are not entitled" is associated with a reduction in the demand for redistribution that is about twice as large as the difference between unemployed workers and employees when it comes to demand for redistribution. Column 5 of table 5 shows that the demand for redistribution is statistically significant and positively associated with the fact of believing that unemployed workers do make efforts to find a job. Column 6 of table 5 shows the same highly significant relation between beliefs about the efforts of employees and support for the welfare state.

Overall, these results show that there is a strong positive relation between the perceived 
civicness of compatriots and support for the welfare state. Obviously, the demand for redistribution could be linked to other motives and beliefs such as the beliefs one holds about the determinants of success Alesina and La Ferrara 2005) or the perception of the fairness of the society (see Alesina and Angeletos 2005). We show in the Online Appendix that our results still hold up when such additional motives are explicitly accounted for.

\section{Conclusion}

This paper shows that the scope of welfare states is associated with trust in a non-trivial way. Large, corrupt and ineffective welfare states can survive thanks to the support of a majority of untrustworthy individuals. The creation of large, transparent and effective welfare states needs a large majority of trustworthy citizens.

These findings might explain why it is so difficult to reform the large welfare states of Continental European countries despite the widespread consensus that they are less effective and transparent than their counterparts in Nordic countries. Our paper suggests that their large size is the consequence of an equilibrium in which the majority of the population is made up of untrustworthy individuals who exploit the advantages provided by the welfare state at the expense of a minority of trustworthy individuals.

The long-run sustainability of this equilibrium is, however, an open question. The fact that all individuals, either trustworthy or untrustworthy, are better off when they are surrounded by trustworthy individuals suggests that all individuals could coordinate to invest in education in order to improve the civic spirit of their offspring, to the extent that education can improve civic spirit (see Glaeser et al. 2007 and Algan et al. 2013). This should improve the effectiveness and the transparency of the welfare state. However, there are also opposing forces at play. Generous welfare states provide numerous individuals with incentives to abuse social benefits and to evade taxation which can undermine civic attitudes (Ljunge 2012). 


\section{References}

Alesina, Alberto, and George-Marios Angeletos. "Fairness and Redistribution." American Economic Review 95, 4: (2005) 960-980.

Alesina, Alberto, Arnaud Devleeschauwer, William Easterly, Sergio Kurlat, and Romain Wacziarg. "Fractionalization." Journal of Economic Growth 8, 2: (2003) 155-94.

Alesina, Alberto, and Nicola Fuchs-Schündeln. "Goodbye Lenin (or Not?): The Effect of Communism on People." American Economic Review 97, 4: (2007) 1507-1528.

Alesina, Alberto, and Paola Giuliano. "Preferences for Redistribution." In Handbook of Social Economics, edited by Alberto Bisin Jess Benhabib, and Matthew O. Jackson, North-Holland, 2011, volume $1,93-131$.

Alesina, Alberto, and Edward Glaeser. Fighting Poverty in the US and Europe: A World of Difference. Oxford University Press, 2004.

Alesina, Alberto, Edward Glaeser, and Bruce Sacerdote. "Why Doesn't the United States Have a European-Style Welfare State?" Brookings Papers on Economic Activity 32, 2: (2001) 187-278.

Alesina, Alberto, and Eliana La Ferrara. "Preferences for redistribution in the land of opportunities." Journal of Public Economics 89, 5-6: (2005) 897-931.

Algan, Yann, Pierre Cahuc, and Andrei Shleifer. "Teaching Practices and Social Capital." American Economic Journal: Applied Economics 5, 3: (2013) 189-210.

Andrews, Donald W K. "Tests for Parameter Instability and Structural Change with Unknown Change Point." Econometrica 61, 4: (1993) 821-56.

Andrews, Donald W. K. "Tests for Parameter Instability and Structural Change with Unknown Change Point: A Corrigendum." Econometrica 71, 1: (2003) 395-397.

Bergh, Andreas, and Christian Bjørnskov. "Historical Trust Levels Predict the Current Size of the Welfare State." Kyklos 64, 1: (2011) 1-19.

Bjørnskov, Christian, and Gert Svendsen. "Does social trust determine the size of the welfare state? Evidence using historical identification." Public Choice 157, 1: (2013) 269-286.

Bénabou, Roland, and Efe A. Ok. "Social Mobility And The Demand For Redistribution: The Poum Hypothesis." The Quarterly Journal of Economics 116, 2: (2001) 447-487.

Chow, Gregory C. "Tests of Equality Between Sets of Coefficients in Two Linear Regressions." Econometrica 28, 3: (1960) pp. 591-605. 
Corneo, Giacomo, and Hans Peter Gruner. "Individual preferences for political redistribution." Journal of Public Economics 83, 1: (2002) 83-107.

Diebold, Francis X., and Celia Chen. "Testing structural stability with endogenous breakpoint A size comparison of analytic and bootstrap procedures." Journal of Econometrics 70, 1: (1996) 221-241.

Esping-Andersen, Gøsta. The Three Worlds of Welfare Capitalism. Princeton University Press, 1990.

Evensky, J. Adam Smith's Moral Philosophy: A Historical and Contemporary Perspective on Markets, Law, Ethics, and Culture. Cambridge University Press, 2005.

Fong, Christina. "Social preferences, self-interest, and the demand for redistribution." Journal of Public Economics 82, 2: (2001) 225-246.

Fong, Christina M., Samuel Bowles, and Herbert Gintis. "Strong reciprocity and the welfare state." In Handbook on the Economics of Giving, Reciprocity and Altruism, edited by S. Kolm, and Jean Mercier Ythier, Elsevier, 2006, volume 1, chapter 23, 1439-1464.

Glaeser, Edward, Giacomo Ponzetto, and Andrei Shleifer. "Why does democracy need education?" Journal of Economic Growth 12, 2: (2007) 77-99.

Hamermesh, Daniel S. "Subjective Outcomes in Economics." Southern Economic Journal 71, 1: (2004) $2-11$.

Hansen, Bruce E. "The New Econometrics of Structural Change: Dating Breaks in U.S. Labour Productivity." Journal of Economic Perspectives 15, 4: (2001) 117-128.

Hetherington, Marc J. "The Political Relevance of Political Trust." The American Political Science Review 92, 4: (1998) pp. 791-808.

- Why Trust Matters: Declining Political Trust and the Demise of American Liberalism. Princeton University Press, 2004.

Ljunge, Martin. "The Spirit of the Welfare State? Adaptation in the Demand for Social Insurance." Journal of Human Capital 6, 3: (2012) 187-223.

Luttens, Roland Iwan, and Marie-Anne Valfort. "Voting for redistribution under desert-sensitive altruism." CORE Discussion Papers 2008053, Université catholique de Louvain, Center for Operations Research and Econometrics (CORE), 2008.

Luttmer, Erzo F. P. "Group Loyalty and the Taste for Redistribution." Journal of Political Economy 109, 3: (2001) 500-528. 
Luttmer, Erzo F. P., and Monica Singhal. "Culture, Context, and the Taste for Redistribution." American Economic Journal: Economic Policy 3, 1: (2011) 157-79.

Milanovic, Branko. "The median-voter hypothesis, income inequality, and income redistribution: an empirical test with the required data." European Journal of Political Economy 16, 3: (2000) 367-410.

Persson, Torsten, and Guido Tabellini. "Political economics and public finance." In Handbook of Public Economics, edited by A. J. Auerbach, and M. Feldstein, Elsevier, 2002, volume 3 of Handbook of Public Economics, chapter 24, 1549-1659.

Piketty, Thomas. "Social Mobility and Redistributive Politics." The Quarterly Journal of Economics 110, 3: (1995) 551-84.

Quandt, Richard E. "Tests of the Hypothesis that a Linear Regression System Obeys Two Separate Regimes." Journal of the American Statistical Association 55, 290: (1960) 324-330.

Rothstein, Bo, Marcus Samanni, and Jan Teorell Luttens. "Quality of Government, Political Power and the Welfare State." QoG Working Paper Series 2010:6, The QOG Institute, 2010.

Rothstein, Bo, and Eric M. Uslaner. "All for All: Equality, Corruption, and Social Trust." World Politics 58, 1: (2005) pp. 41-72.

Scruggs, Lyle. "Welfare State Entitlements Data Set: A Comparative Institutional Analysis of Eighteen Welfare States.", 2004.

Smith, Adam. An Inquiry into the Nature and Causes of the Wealth of Nations. London: Methuen \& Co., Ltd., 1904. 
Figure 1: The twin peaks relationship between the generosity of the welfare state, trust, and corruption perception.

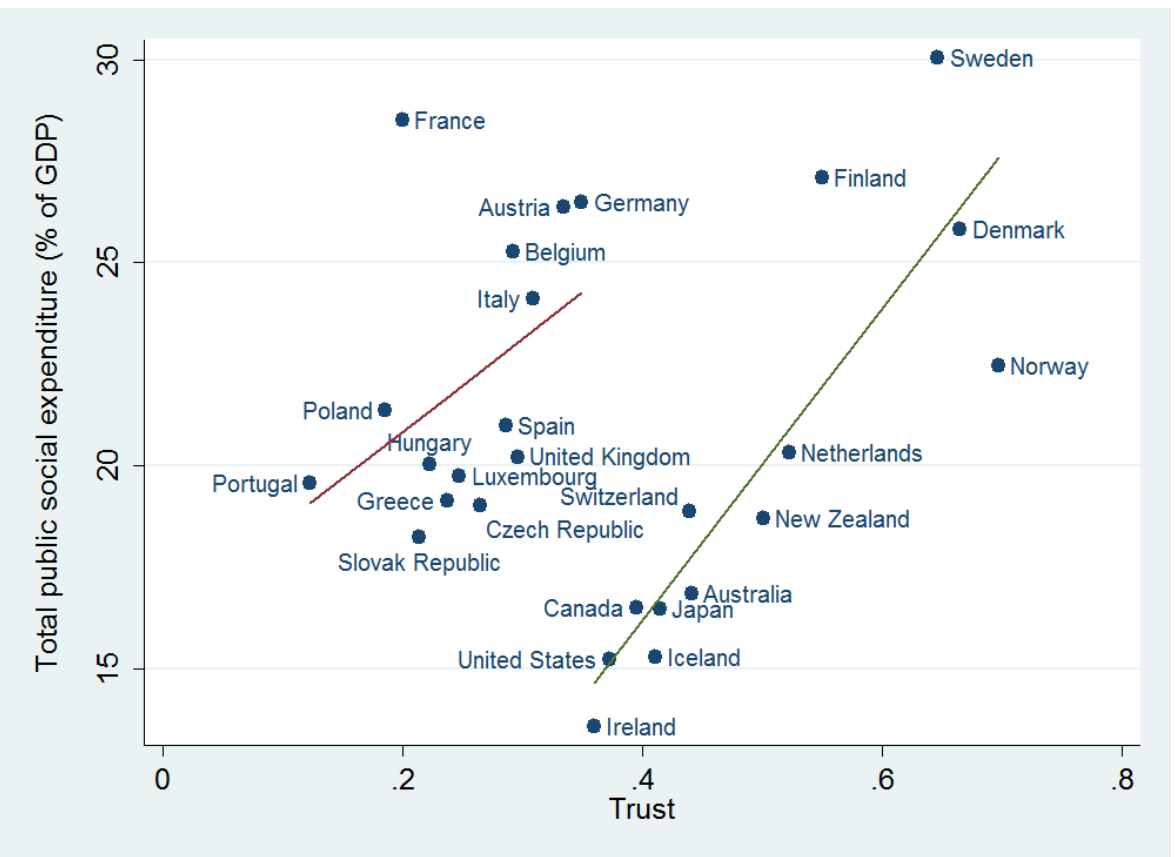

(a) Public social expenditure and trust.

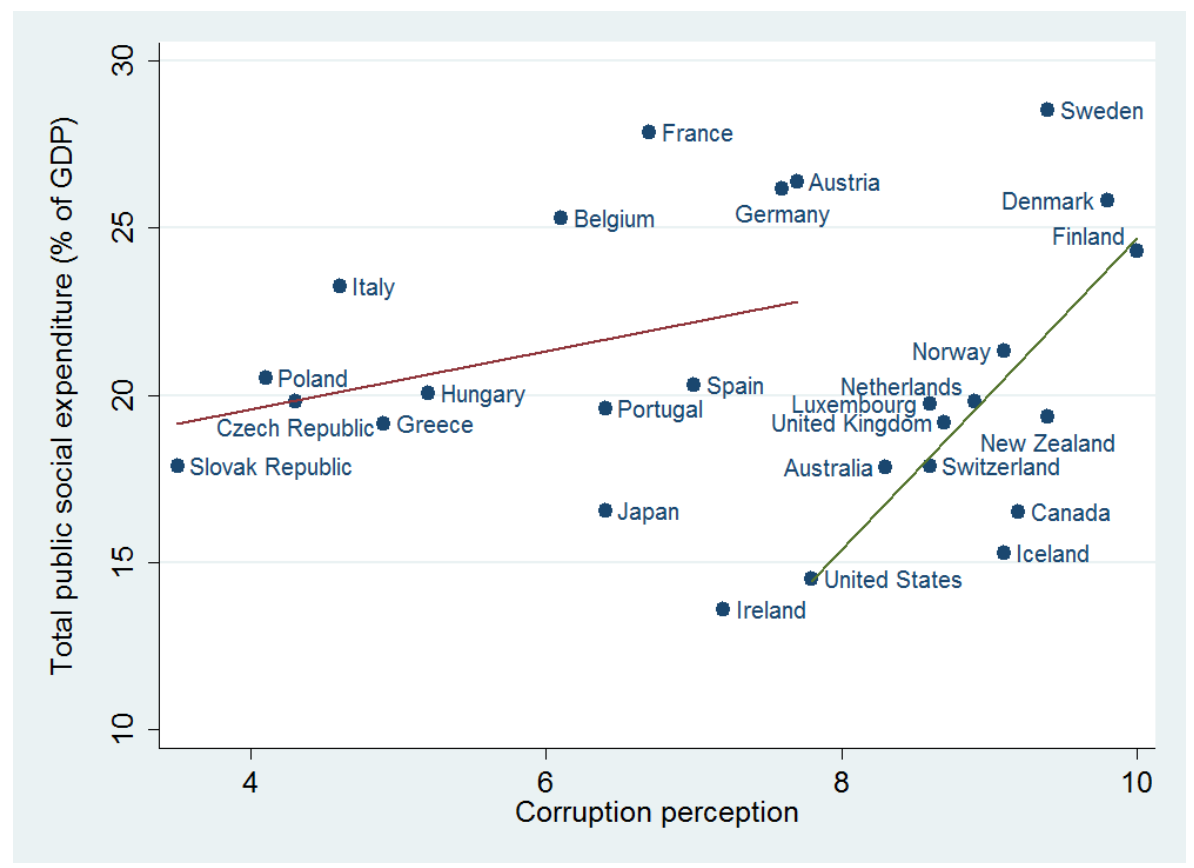

(b) Public social expenditure and corruption perception.

Sources: World Values Survey, OECD Social Expenditure Database, and Transparency International. Trust is the share of respondents who answer "most people can be trusted" to the following question of the World Values Survey: "Generally speaking, would you say that most people can be trusted or that you need to be very careful in dealing with people?". See section 3 for the presentation of the procedure used to construct regressions' lines. 
Figure 2: The relation between the share of trustworthy individuals and the scope of the welfare state.

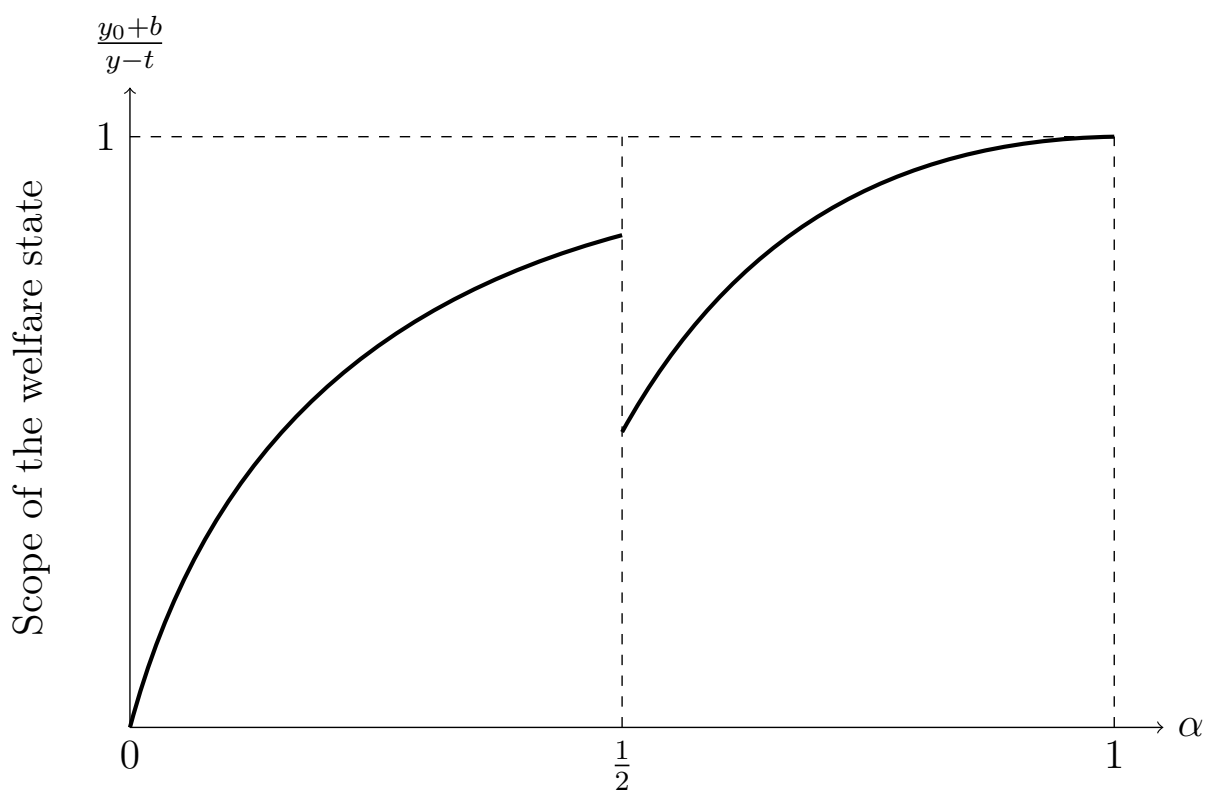

Share of trustworthy individuals 


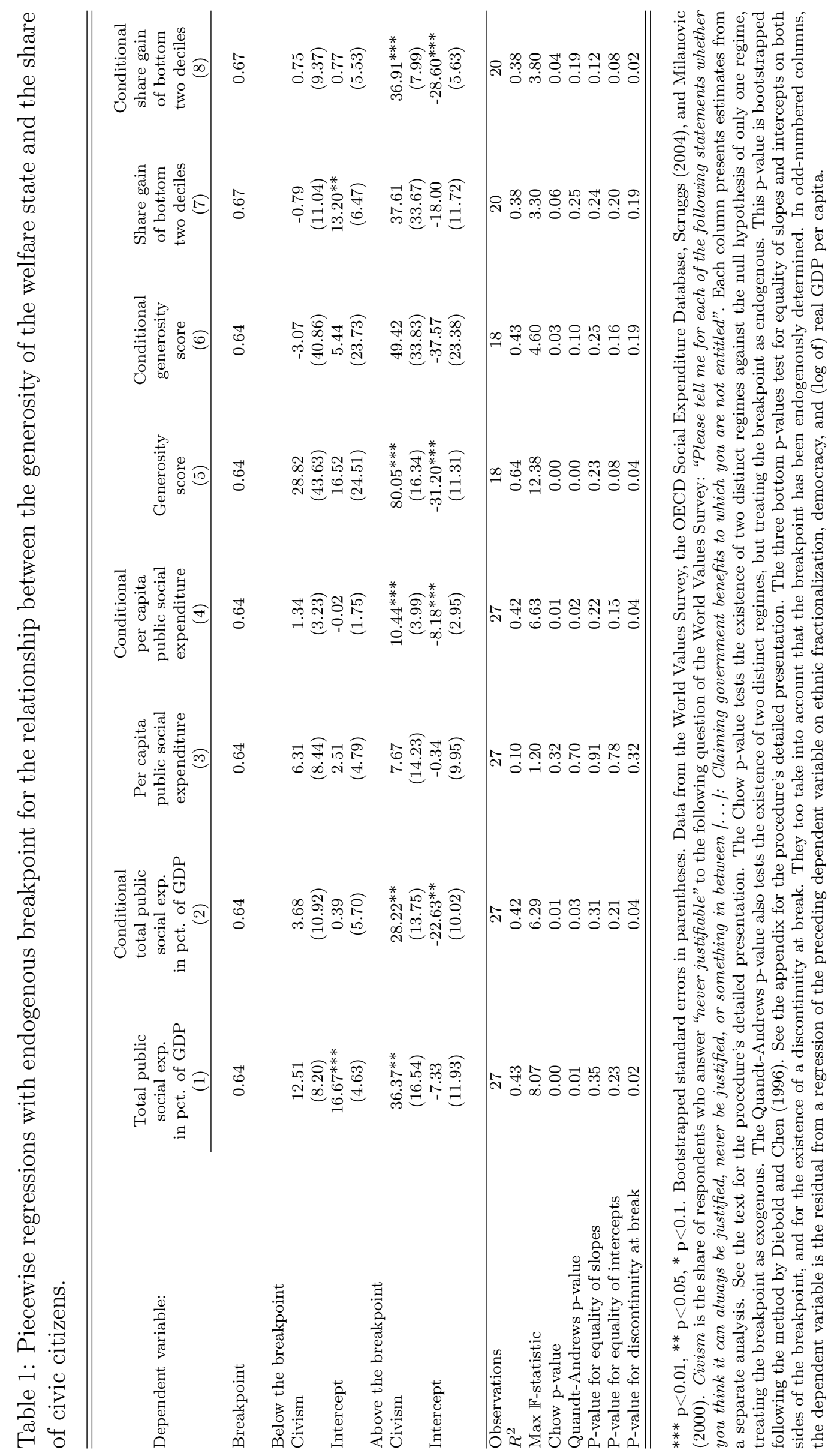




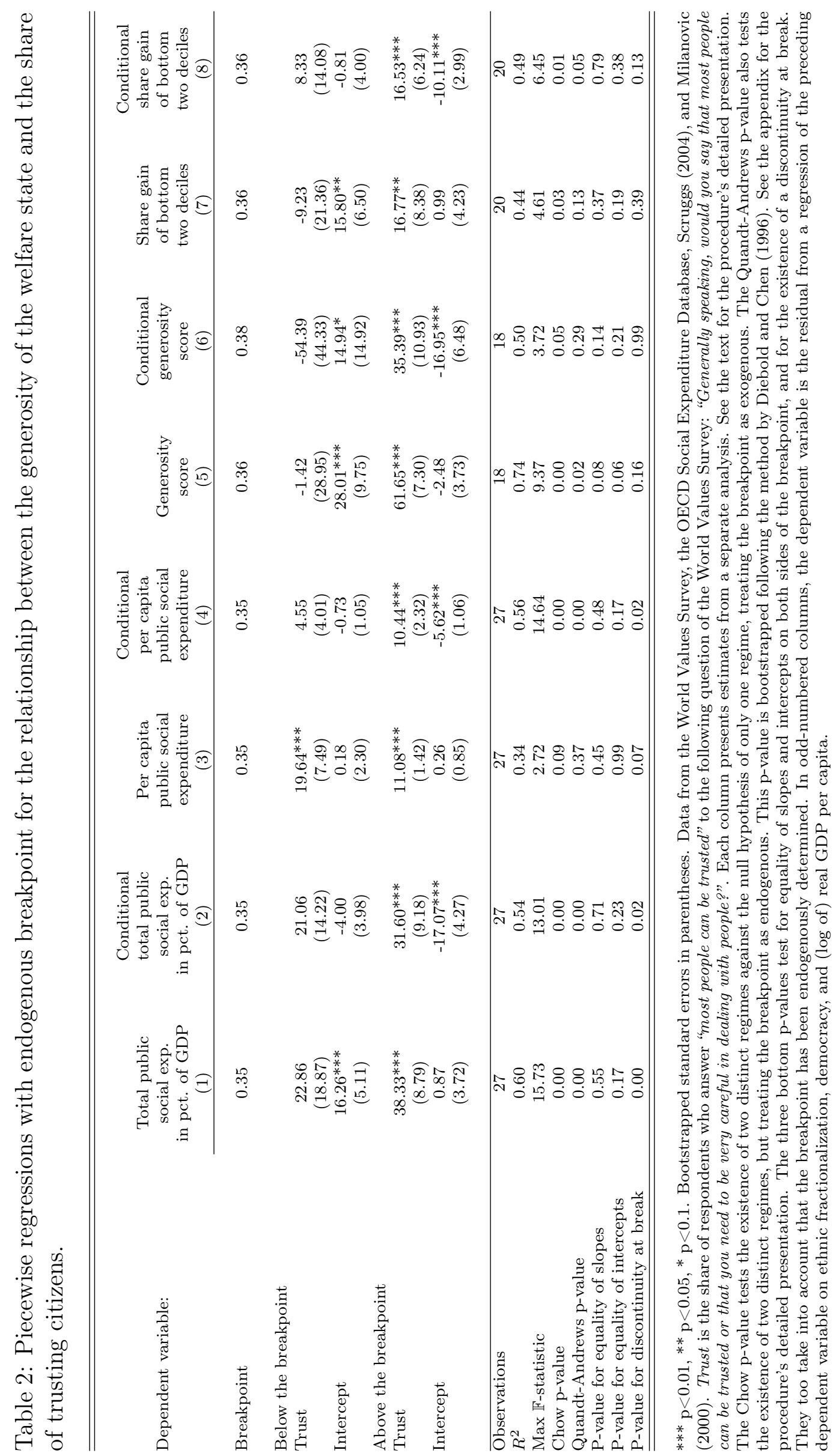




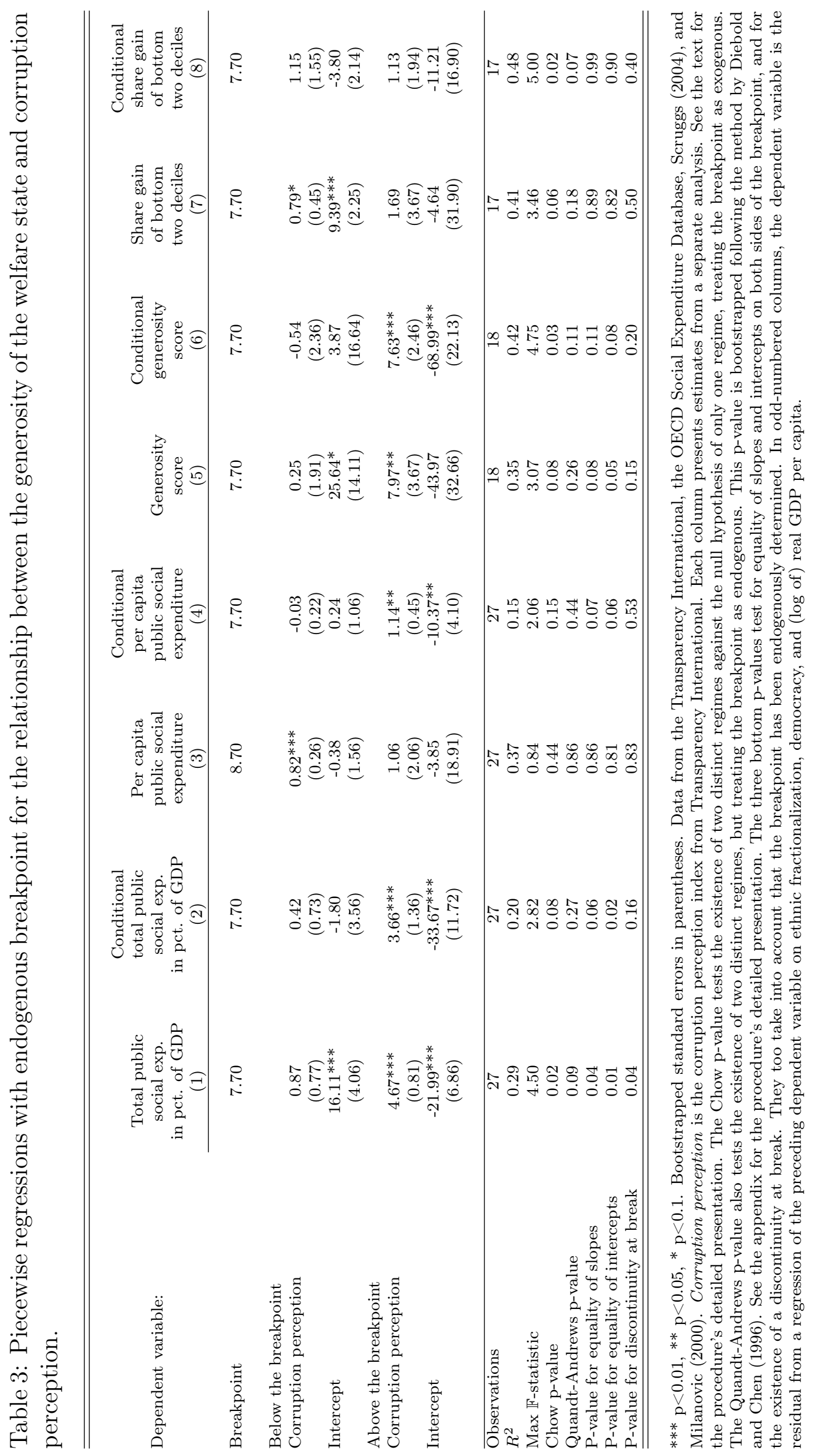


Table 4: Relationship between the support for the welfare state and civism, measured using different questions.

Dependent variable: support for the welfare state

(1)

(2)

(3)

$\begin{array}{cc}-0.162^{* * *} & \\ (0.035) & \\ & -0.149^{* * *} \\ & (0.037)\end{array}$

Civism (taxes)

Civism (bribe)

Civism (litter)

Civism (stolen goods)

Trust

Age

Male

Education

Income

Religiosity

Political orientation

Married

Separated / Divorced

Widowed

Never married

Employed

Unemployed

In education

Retired

Other

0.001
$(0.001)$
$-0.101 * * *$
$(0.021)$
$-0.108^{* * *}$
$(0.009)$
$-0.090^{* * *}$
$(0.009)$

$(0.009)$

0.003

(0.006)

$-0.138^{* * *}$

(0.010)

Reference

\subsection{0}

$(0.042)$

0.057

(0.042)

0.007

(0.028)

Reference

$0.139^{* * *}$

(0.038)

0.054

(0.049)

$0.130^{* * *}$

$(0.046)$

$0.065^{* *}$

(0.033)
(0.037)

$$
0.001
$$

(0.001)

$-0.099 * * *$

(0.022)

$-0.105^{* * *}$

(0.008)

$-0.095^{* * *}$

(0.009)

0.002

(0.006)

$-0.138^{* * *}$

(0.011)

Reference

\section{$-0.009$}

$(0.042)$

0.045

(0.043)

0.013

(0.030)

Reference

(0.040)

0.052

(0.050)

$0.114^{* *}$

$0.066^{*}$

$$
\begin{array}{r}
-0.072^{* *} \\
(0.036)
\end{array}
$$

$-0.082^{* *}$

(0.035)

$$
\begin{gathered}
-0.292^{* * *} \\
(0.076)
\end{gathered}
$$

$$
\begin{gathered}
-0.188^{* * *} \\
(0.056)
\end{gathered}
$$

$0.166^{* * *}$

(0.030)

\subsection{1}

(0.001)

$-0.098^{* * *}$

(0.021)

$-0.106^{* * *}$

(0.009)

$-0.092^{* * *}$

(0.009)

0.003

(0.006)

$-0.137^{* * *}$

(0.010)

Reference

$$
\begin{gathered}
0.001 \\
(0.001) \\
-0.097^{* * *} \\
(0.021) \\
-0.106^{* * *} \\
(0.009) \\
-0.092^{* * *} \\
(0.009) \\
0.003 \\
(0.005) \\
-0.138^{* * *} \\
(0.010) \\
\text { Reference }
\end{gathered}
$$

$$
\begin{gathered}
0.002 \\
(0.003) \\
-0.205^{* * *} \\
(0.051) \\
-0.136^{* * *} \\
(0.021) \\
-0.086^{* * *} \\
(0.013) \\
0.035^{* *} \\
(0.013) \\
-0.174^{* * *} \\
(0.022) \\
\text { Reference }
\end{gathered}
$$

\section{$-0.001$}

(0.002)

$-0.097^{* *}$

(0.036)

$-0.133^{* * *}$

(0.013)

$-0.099^{* * *}$

(0.017)

0.011

(0.009)

$-0.150^{* * *}$

(0.019)

0.000

(0.001)

$-0.087^{* * *}$

(0.020)

$-0.107^{* * *}$

(0.009)

$-0.094^{* * *}$

(0.009)

0.001

(0.005)

$-0.137^{* * *}$

(0.010)

Reference

Reference

0.003

$(0.042)$

0.057

(0.042)

0.021

(0.028)

Reference

0.000

(0.043)

$-0.095$

(0.108)

0.061

(0.042)

0.022

$-0.026$

(0.085)

(0.028)

$-0.003$

(0.070)

Reference

Reference

$-0.021$

(0.089)

$-0.000$

$(0.042)$

0.057

$(0.076) \quad(0.041)$

$\begin{array}{ll}-0.068 & 0.011\end{array}$

(0.050) (0.028)

$0.137^{* * *} \quad 0.136^{* * *}$

(0.039)

$0.138^{* * *}$

0.087

(0.039)

(0.060)

Reference

Reference

0.050

(0.049)

$0.128^{* * *}$

0.044

$-0.135$

$0.160^{* *}$

$(0.077)$

$0.145^{* * *}$

$(0.048) \quad(0.095)$

$0.130^{* * *}$

(0.045)

0.180

0.070 **

(0.107)

0.065

$(0.039)$

(0.096)

$0.199 * * *$

0.066

$0.071^{* *}$

(0.032)

$(0.066)$

0.032

$0.129^{* * *}$

(0.034)

(0.032)

(0.060)

(0.063)

$(0.045)$

0.046

$(0.035)$

\begin{tabular}{lccccccc}
\hline Observations & 138965 & 133242 & 141945 & 142192 & 22538 & 47757 & 144291 \\
R-squared & 0.111 & 0.109 & 0.110 & 0.110 & 0.154 & 0.105 & 0.113 \\
\hline \hline
\end{tabular}

*** $\mathrm{p}<0.01, * * \mathrm{p}<0.05, * \mathrm{p}<0.1$. White heteroskedastic standard errors (clustered by country $\times$ wave) in parentheses. OLS regressions. Data from World Values Survey. All regressions include year and country fixed effects, and a constant term. The support for the welfare state is measured using the following question: "I'd like you to tell me your views on various issues. How would you place your views on this scale? 1 means you agree completely with the statement on the left; 10 means you agree completely with the statement on the right; and if your views fall somewhere in between, you can choose any number in between. We need larger income differences as incentives versus Incomes should be made more equal". Variables starting with Civism are equal to 1 if the respondent answers "never justifiable" to the following question: "Please tell me for each of the following statements whether you think it can always be justified, never be justified, or something in between, using this card"; variables are equal to 0 for all other answers. Statements used are: "Claiming government benefits to which you are not entitled"; "Avoiding a fare on public transport"; "Cheating on taxes when you have a chance"; "Someone accepting a bribe in the course of their duties"; "Throwing away litter in a public place"; "Buying stolen goods". Trust is measured using the following question: "Generally speaking, would you say that most people can be trusted or that you need to be very careful in dealing with people?" The variable equals 1 for "Most people can be trusted" and 0 for "Can't be too careful". Other covariates are described in the appendix. 
Table 5: Relationship between the support for the welfare state, trust, and perceived behavior of compatriots.

Dependent variable: support for the welfare state

(1)

(2)

(3)

(4)

(5)

(6)

Most people can be trusted

Most people try to be fair

(0.013)

Most people try to be helpful

Many people manage to obtain benefits and

services to which they are not entitled

Most unemployed people do not

really try to find a job

Employees often pretend they are

sick in order to stay at home

Age

Male

Education

Income

Religiosity

Political orientation

Married

Separated / Divorced

Widowed

Never married

Employed

Unemployed

In education

Disabled

Retired

Other
$0.052^{* * *}$

(0.013)

\begin{tabular}{|c|c|c|c|c|c|c|}
\hline Most people try to be helpful & & & $\begin{array}{c}0.047^{* * *} \\
(0.012)\end{array}$ & & & \\
\hline $\begin{array}{l}\text { Many people manage to obtain benefits and } \\
\text { services to which they are not entitled }\end{array}$ & & & & $\begin{array}{c}0.203^{* * *} \\
(0.027)\end{array}$ & & \\
\hline $\begin{array}{l}\text { Most unemployed people do not } \\
\text { really try to find a job }\end{array}$ & & & & & $\begin{array}{c}0.231^{* * *} \\
(0.037)\end{array}$ & \\
\hline $\begin{array}{l}\text { Employees often pretend they are } \\
\text { sick in order to stay at home }\end{array}$ & & & & & & $\begin{array}{c}0.178^{* * *} \\
(0.027)\end{array}$ \\
\hline Age & $\begin{array}{c}0.010^{* * *} \\
(0.001)\end{array}$ & $\begin{array}{c}0.010^{* * *} \\
(0.001)\end{array}$ & $\begin{array}{c}0.010^{* * *} \\
(0.001)\end{array}$ & $\begin{array}{c}0.011^{* * *} \\
(0.002)\end{array}$ & $\begin{array}{c}0.010^{* * *} \\
(0.001)\end{array}$ & $\begin{array}{c}0.010^{* * *} \\
(0.002)\end{array}$ \\
\hline Male & $\begin{array}{l}-0.049 \\
(0.037)\end{array}$ & $\begin{array}{l}-0.039 \\
(0.038)\end{array}$ & $\begin{array}{l}-0.041 \\
(0.038)\end{array}$ & $\begin{array}{l}-0.051 \\
(0.038)\end{array}$ & $\begin{array}{l}-0.050 \\
(0.038)\end{array}$ & $\begin{array}{l}-0.036 \\
(0.037)\end{array}$ \\
\hline Education & $\begin{array}{c}0.015^{* *} \\
(0.007)\end{array}$ & $\begin{array}{l}0.017^{* *} \\
(0.007)\end{array}$ & $\begin{array}{l}0.018^{* *} \\
(0.007)\end{array}$ & $\begin{array}{c}0.016^{* *} \\
(0.007)\end{array}$ & $\begin{array}{l}0.012^{*} \\
(0.007)\end{array}$ & $\begin{array}{l}0.015^{*} \\
(0.007)\end{array}$ \\
\hline Income & $\begin{array}{c}0.002 \\
(0.010)\end{array}$ & $\begin{array}{c}0.004 \\
(0.010)\end{array}$ & $\begin{array}{c}0.006 \\
(0.009)\end{array}$ & $\begin{array}{c}0.004 \\
(0.009)\end{array}$ & $\begin{array}{c}0.004 \\
(0.010)\end{array}$ & $\begin{array}{c}0.004 \\
(0.009)\end{array}$ \\
\hline Religiosity & $\begin{array}{c}0.014^{* *} \\
(0.006)\end{array}$ & $\begin{array}{c}0.015^{* *} \\
(0.006)\end{array}$ & $\begin{array}{c}0.015^{* *} \\
(0.006)\end{array}$ & $\begin{array}{c}0.016^{* *} \\
(0.006)\end{array}$ & $\begin{array}{c}0.017^{* * *} \\
(0.006)\end{array}$ & $\begin{array}{c}0.019^{* * *} \\
(0.006)\end{array}$ \\
\hline Political orientation & $\begin{array}{c}-0.117^{* * * *} \\
(0.029)\end{array}$ & $\begin{array}{c}-0.118^{* * * *} \\
(0.029)\end{array}$ & $\begin{array}{c}-0.117^{* * * *} \\
(0.029)\end{array}$ & $\begin{array}{c}-0.112^{* * * *} \\
(0.028)\end{array}$ & $\begin{array}{c}-0.104^{* * * *} \\
(0.027)\end{array}$ & $\begin{array}{c}-0.112^{* * *} \\
(0.028)\end{array}$ \\
\hline Married & Reference & Reference & Reference & Reference & Reference & Reference \\
\hline Separated / Divorced & $\begin{array}{l}-0.028 \\
(0.050)\end{array}$ & $\begin{array}{l}-0.031 \\
(0.049)\end{array}$ & $\begin{array}{l}-0.030 \\
(0.048)\end{array}$ & $\begin{array}{l}-0.038 \\
(0.048)\end{array}$ & $\begin{array}{l}-0.036 \\
(0.048)\end{array}$ & $\begin{array}{l}-0.025 \\
(0.050)\end{array}$ \\
\hline Widowed & $\begin{array}{c}-0.102^{* *} \\
(0.044)\end{array}$ & $\begin{array}{c}-0.107^{* *} \\
(0.042)\end{array}$ & $\begin{array}{c}-0.106^{* *} \\
(0.044)\end{array}$ & $\begin{array}{c}-0.094^{* *} \\
(0.041)\end{array}$ & $\begin{array}{c}-0.098^{* *} \\
(0.043)\end{array}$ & $\begin{array}{c}-0.098^{* *} \\
(0.045)\end{array}$ \\
\hline Never married & $\begin{array}{c}0.094^{* * *} \\
(0.031)\end{array}$ & $\begin{array}{c}0.093^{* * *} \\
(0.030)\end{array}$ & $\begin{array}{c}0.100^{* * *} \\
(0.031)\end{array}$ & $\begin{array}{c}0.108^{* * *} \\
(0.033)\end{array}$ & $\begin{array}{c}0.102^{* * *} \\
(0.032)\end{array}$ & $\begin{array}{c}0.108^{* * *} \\
(0.032)\end{array}$ \\
\hline Employed & Reference & Reference & Reference & Reference & Reference & Reference \\
\hline Unemployed & $\begin{array}{c}0.167^{* *} \\
(0.061)\end{array}$ & $\begin{array}{c}0.163^{* *} \\
(0.062)\end{array}$ & $\begin{array}{c}0.157^{* *} \\
(0.061)\end{array}$ & $\begin{array}{c}0.129^{* *} \\
(0.060)\end{array}$ & $\begin{array}{c}0.084 \\
(0.055)\end{array}$ & $\begin{array}{c}0.134^{* *} \\
(0.063)\end{array}$ \\
\hline In education & $\begin{array}{l}0.195^{* *} \\
(0.091)\end{array}$ & $\begin{array}{c}0.200^{* *} \\
(0.089)\end{array}$ & $\begin{array}{c}0.208^{* *} \\
(0.088)\end{array}$ & $\begin{array}{c}0.195^{* *} \\
(0.089)\end{array}$ & $\begin{array}{c}0.193^{* *} \\
(0.089)\end{array}$ & $\begin{array}{l}0.205^{* *} \\
(0.086)\end{array}$ \\
\hline Disabled & $\begin{array}{c}0.304^{* * *} \\
(0.096)\end{array}$ & $\begin{array}{c}0.285^{* * *} \\
(0.099)\end{array}$ & $\begin{array}{c}0.283^{* * *} \\
(0.095)\end{array}$ & $\begin{array}{c}0.247^{* *} \\
(0.092)\end{array}$ & $\begin{array}{c}0.274^{* * *} \\
(0.093)\end{array}$ & $\begin{array}{c}0.241^{* *} \\
(0.097)\end{array}$ \\
\hline Retired & $\begin{array}{c}0.164^{* * *} \\
(0.046)\end{array}$ & $\begin{array}{c}0.156^{* * *} \\
(0.046)\end{array}$ & $\begin{array}{c}0.152^{* * *} \\
(0.046)\end{array}$ & $\begin{array}{c}0.160^{* * *} \\
(0.045)\end{array}$ & $\begin{array}{c}0.175^{* * *} \\
(0.045)\end{array}$ & $\begin{array}{c}0.173^{* * *} \\
(0.042)\end{array}$ \\
\hline Other & $\begin{array}{c}0.082 \\
(0.058)\end{array}$ & $\begin{array}{c}0.081 \\
(0.058)\end{array}$ & $\begin{array}{c}0.081 \\
(0.058)\end{array}$ & $\begin{array}{c}0.073 \\
(0.059)\end{array}$ & $\begin{array}{c}0.071 \\
(0.056)\end{array}$ & $\begin{array}{c}0.086 \\
(0.054)\end{array}$ \\
\hline Observations & 30605 & 30505 & 30570 & 29795 & 30394 & 29882 \\
\hline R-squared & 0.094 & 0.091 & 0.091 & 0.097 & 0.102 & 0.097 \\
\hline
\end{tabular}

*** $\mathrm{p}<0.01,{ }^{* *} \mathrm{p}<0.05, * \mathrm{p}<0.1$. White heteroskedastic standard errors (clustered at the country level) in parentheses. OLS regressions. Data from European Social Survey, round 4. All regressions include country fixed effects and a constant term. The support for the welfare state is measured using the following question: "Many social benefits and services are paid by taxes. If the government had to choose between increasing taxes and spending more on social benefits and services, or decreasing taxes and spending less on social benefits and services, which should they do?". Answers range from 0, "Government should decrease taxes a lot and spend much less on social benefits and services", to 10, "Government should increase taxes a lot and spend much more on social benefits and services". The variable most people can be trusted is the answer, on a scale from 0 to 10, to the following question: "Generally speaking, would you say that most people can be trusted or that you need to be very careful in dealing with people?". The variable most people try to be fair is the answer, on a scale from 0 to 10 , to the following question: "Do you think that most people would try to take advantage of you if they got a chance, or would they try to be fair?". The variable most people try to be helpful is the answer, on a scale from 0 to 10, to the following question: "Would you say that most of the time people try to be helpful or that they are mostly looking out for themselves?". The last three independent variables are approvals to the following statements: "Many people manage to obtain benefits and services to which they are not entitled", "Most unemployed people do not really try to find a job", and "Employees often pretend they are sick in order to stay at home". Answers range from 1 if the respondent agrees strongly, to 5 if he disagrees strongly. Other covariates are described in the appendix. 